\title{
Profesor dr hab. med. Barbara Lecewicz-Toruń (1932-2020)
}

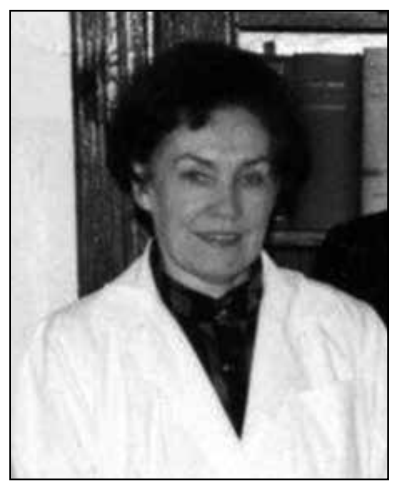

W dniu 14 lutego 2020 roku pożegnaliśmy prof. Barbarę Lecewicz-Torun, wieloletniego kierownika Katedry i Kliniki Dermatologicznej Akademii Medycznej w Lublinie, wieloletniego konsultanta wojewódzkiego w dziedzinie dermatologii i wenerologii oraz wieloletnią przewodniczącą Oddziału Lubelskiego Polskiego Towarzystwa Dermatologicznego.

Profesor Lecewicz-Toruń urodziła się 9 września 1932 roku w Kraśniku. Studiowała na Wydziale Lekarskim ówczesnej Akademii Medycznej w Lublinie, w 1955 roku uzyskała dyplom lekarza medycyny. Po studiach lekarskich cała Jej praca zawodowa i naukowa związana była z Kliniką Dermatologiczną Akademii Medycznej w Lublinie. Specjalizację I stopnia z dermatologii i wenerologii zdobyła w 1957 roku, a tytuł specjalisty dermatologa i wenerologa w 1962 roku. Stopień doktora nauk medycznych uzyskała w 1965 roku na podstawie pracy doktorskiej realizowanej pod kierunkiem prof. Romana Michałowskiego - ówczesnego kierownika Kliniki Dermatologicznej Akademii Medycznej w Lublinie. Pełniła obowiązki kierownika Kliniki w latach 1983-1984 (po odejściu na emeryturę prof. Romana Michałowskiego) oraz w latach 1987-1988 (po śmierci kolejnego kierownika doc. Jana Kudejki). W 1988 roku obroniła rozprawę habilitacyjną i uzyskała stopień naukowy doktora habilitowanego nauk medycznych. W 1988 roku na podstawie postępowania konkursowego objęła stanowisko kierownika Kliniki Dermatologicznej Akademii Medycznej w Lublinie, które zajmowała do odejścia na emeryturę w 2002 roku. W 2000 roku otrzymała tytuł naukowy profesora medycyny. Była autorką i współautorką licznych prac badawczych, promotorką rozpraw doktorskich, kierownikiem specjalizacji wielu lekarzy dermatologów.

Przywiązywała ogromną wagę do ustawicznego kształcenia, czuła się szczególnie odpowiedzialna za szkolenie młodych lekarzy, zachęcała wszystkich do stałego rozwoju zawodowego i naukowego. Charakterystyczną cechą Jej osobowości była wielka życzliwość i cierpliwość dla pacjentów, empatia, zrozumienie ich potrzeb i oczekiwań.

Profesor Barbara Lecewicz-Toruń zmarła 10 lutego 2020 roku w wieku 88 lat. Zapamiętamy Ją jako wybitnego, dociekliwego klinicystę, wielki autorytet w zakresie patogenezy i leczenia łuszczycy, zaangażowanego nauczyciela wielu pokoleń lekarzy, energiczną organizatorkę konferencji i kursów dermatologicznych. W uznaniu zasług prof. Lecewicz-Toruń została uhonorowana m.in. Krzyżem Kawalerskim Orderu Odrodzenia Polski, Złotym Krzyżem Zasługi, Medalem Komisji Edukacji Narodowej, Odznaką "Za wzorową pracę w służbie zdrowia" oraz innymi nagrodami za pracę zawodową i społeczną.

Grażyna Chodorowska

How to cite this article

Chodorowska G.: Profesor dr hab. med. Barbara Lecewicz-Toruń (1932-2020). Dermatol Rev/Przegl Dermatol 2020, 107, 91. DOI: https://doi.org/10.5114/dr.2019.85582. 